\title{
Spheroplasts of Synechococcus PCC 6301
}

\author{
By S. F. DELANEY† \\ School of Botany, University of New South Wales, PO Box 1, Kensington, NSW 2033, Australia
}

(Received II May 1984)

Of a number of osmotic stabilizers tested, $0.5 \mathrm{M}$-L-proline was the most suitable for the formation of spheroplasts of Synechococcus PCC 6301 with minimal loss of viability. However, even this stabilizer inhibited colony formation.

\section{INTRODUCTION}

The ability to make spheroplasts of cyanobacteria has been important for a number of physiological studies, for example the assimilation of nucleic acid precursors (Pigott \& Carr, 1971) and the activities of periplasmic enzymes (Peschek et al., 1982). Despite this no attempt has been made to determine the optimal conditions for spheroplast formation. For this reason and to determine whether spheroplast fusion (Hopwood, 1981) would be a suitable means of genetic analysis in these organisms, appropriate conditions were developed for the efficient production of spheroplasts of Synechococcus PCC 6301 with high viability.

\section{METHODS}

Synechococcus PCC 6301 (Rippka et al., 1979) was cultured in BG-11 medium (Rippka et al., 1979) at $34^{\circ} \mathrm{C}$ in warm white fluorescent light $\left(109 \pm 7 \mathrm{E} \mathrm{m}^{-2} \mathrm{~s}^{-1}\right)$. Liquid medium was supplemented with $\mathrm{NaHCO}_{3}\left(1 \mathrm{~g}^{-1}\right)$ before autoclaving. Liquid cultures $(20 \mathrm{ml})$ in $25 \times 150 \mathrm{~mm}$ tubes were gassed $(10 \mathrm{ml} \mathrm{min}-1)$ with $5 \%(\mathrm{v} / \mathrm{v}) \mathrm{CO}_{2}$ in air (Commonwealth Industrial Gases) through a Pasteur pipette. Using a $2.5 \%$ to $5 \%(\mathrm{v} / \mathrm{v})$ inoculum a cell density of approximately $2 \times 10^{8} \mathrm{ml}^{-1}$ was obtained after overnight incubation. Dilutions were made in BG-11. Solid medium was prepared according to Rippka et al. (1979), using $1 \cdot 25 \%(w / v)$ Difco Bacto-agar. Plates were sealed in Perspex boxes or clear plastic bags to prevent desiccation and incubated in a Gared Thermoline (Smithfield. NSW, Australia) illuminated incubator. Colonies could be counted after 3 to $4 \mathrm{~d}$.

Lysozyme (Bochringer Mannheim) was prepared as a stock solution (10 $\mathrm{mg} \mathrm{m}^{-1}$ ) in distilled water, filter sterilized and stored at $-20^{\circ} \mathrm{C}$. Osmotic stabilizers (Sigma) were prepared at double strength and autoclaved or filter sterilized. Stabilizers were always used with BG-11, equal volumes of each at double strength being mixed. For spheroplast preparation an overnight culture was harvested $\left(500 \mathrm{~g}_{\mathrm{g}}\right.$, room temperature) and resuspended in 0.1 vol. stabilized BG-11. Lysozyme was added at a final concentration of $0.05 \%(w / v)$ (Pigott \& Carr, 1971) and the suspension shaken gently $\left(80\right.$ oscillations $\left.\min ^{-1}\right)$ at $34^{\circ} \mathrm{C}$ in the dark without gassing. Unless otherwise indicated incubations were for $3 \mathrm{~h}$.

Spheroplast frequencies were determined microscopically using Köhler illumination and oil immersion. At least 100 organisms were counted. Spheroplast viability was estimated microscopically by methylene blue exclusion (Gurr, 1965). For this, spheroplasts were diluted tenfold into a $0.25 \%(w / v)$ aqueous solution of methylene blue containing the appropriate osmotic stabilizer. By this technique fresh cells were observed to be $100 \%$ viable. Total counts were determined using a Neubauer counting chamber.

\section{RESULTS AND DISCUSSION}

In initial experiments 0.5 M-mannitol (Pigott \& Carr, 1971) was used as the osmotic stabilizer and $92 \%$ of the organisms were converted to spheroplasts after $6 \mathrm{~h}$ (Fig. 1). Although an efficient stabilizer, mannitol was toxic to both cells and spheroplasts of Synechococcus, even after a short exposure (Table 1). For this reason a number of osmotic stabilizers were tested for their toxicity

† Present address: School of Biotechnology, University of New South Wales, Kensington, NSW 2033, Australia. 


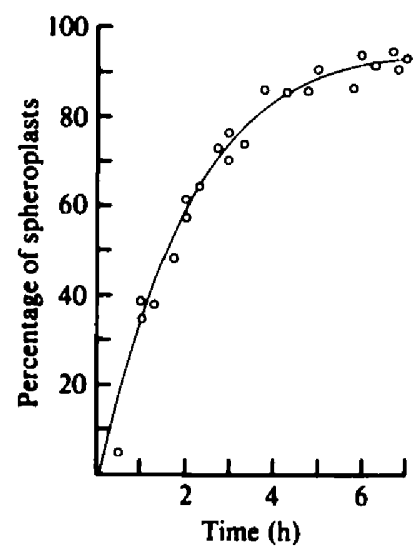

Fig. 1

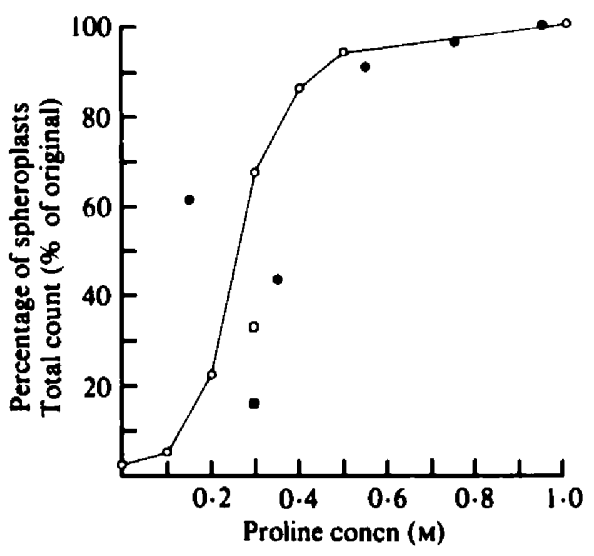

Fig. 2

Fig. 1. Formation of spheroplasts of Synechococcus PCC 6301 in the presence of 0.5 M-D-mannitol.

Fig. 2. Effect of $L$-proline concentration on spheroplast formation $(O)$ and total count (cells + spheroplasts) (O). Spheroplast frequency in the presence of $10 \mathrm{mu}-\mathrm{MgSO}_{4}(\square)$ or $10 \mathrm{mu}-\mathrm{CaCl}_{2}(\square)$ is also shown.

Table 1. Effect of osmotic stabilizers on the formation and viability of spheroplasts, and on survival of cells of Synechococcus PCC 6301

Spheroplast frequencies after incubation for $3 \mathrm{~h}$ in lysozyme are shown \pm SD, with the number of determinations in parentheses. Spheroplast viability was estimated by methylene blue exclusion as described in Methods. Cell survival was determined from colony counts after cells had been incubated in the presence of stabilizer, without lysozyme, for $\mathbf{4 h}$. ND, Not determined.

\begin{tabular}{lccccc}
$\begin{array}{c}\text { Osmotic } \\
\text { stabilizer }\end{array}$ & Concn & \multicolumn{2}{c}{$\begin{array}{c}\text { Percentage of } \\
\text { spheroplasts } \\
\text { after } 3 \mathrm{~h}\end{array}$} & $\begin{array}{c}\text { Spheroplast } \\
\text { viability } \\
\text { after } 3 \mathrm{~h} \mathrm{( \% )}\end{array}$ & $\begin{array}{c}\text { Cell survival } \\
\text { after } 4 \mathrm{~h} \mathrm{( \% )}\end{array}$ \\
L-Proline & $1.0 \mathrm{M}$ & 100 & $(1)$ & 81 & ND \\
L-Proline & $0.5 \mathrm{M}$ & $90 \pm 8(19)$ & 85 & 94 \\
D-Sorbitol & $0.5 \mathrm{M}$ & $85 \pm 8$ & $(2)$ & ND & 15 \\
Sucrose & $20 \%(\mathbf{w} / \mathrm{v})$ & $81 \pm 13(2)$ & ND & 2 \\
D-Mannitol & $0.5 \mathrm{M}$ & $65 \pm 13(8)$ & 0 & 4 \\
Glycerol & $2.0 \mathrm{M}$ & 13 & $(1)$ & 0 & 100 \\
Glycerol & $1.0 \mathrm{M}$ & $18 \pm 9$ & $(3)$ & 0 & 98 \\
Glycerol & $0.5 \mathrm{M}$ & $9 \pm 9$ & $(6)$ & 67 & 99
\end{tabular}

as well as their ability to support spheroplast formation. Mannitol, sorbitol and sucrose were toxic to cells, resulting in low survival after organisms were exposed to the stabilizer for $4 \mathrm{~h}$ (Table 1). Proline and glycerol were non-toxic to cells, but only proline supported high frequencies of spheroplasts with good viability. The toxicity of glycerol at concentrations greater than $0.5 \mathrm{M}$ in the presence of lysozyme but not in its absence (Table 1 ) cannot be accounted for by the observed conversion of cells to spheroplasts. However, the low observed spheroplast frequency could be due to incomplete spheroplast formation, where osmotically fragile cells are formed (and are inviable under these conditions) without loss of cell shape. This is consistent with the observation that dilution of spheroplasts to a stabilizer concentration of $0.1 \mathrm{M}$ caused an increase in spheroplast frequency. A similar phenomenon has been observed in Escherichia coli (Martin, 1963).

An appreciable difference in the effect of proline was observed when it was autoclaved separately from, or together with, BG-11. High yields of spheroplasts were obtained only when the proline was autoclaved separately from the BG-11. When it was autoclaved together with BG-11 a low frequency $(11 \%)$ of spheroplasts was obtained although cell survival $(89 \%)$ and spheroplast viability $(85 \%)$ were normal. Presumably at high temperature components of BG-11 
interact with proline to produce a lysozyme inhibitor. This effect was not observed with any of the other osmotic stabilizers.

In subsequent experiments proline was used as the osmotic stabilizer. The optimal proline concentration ( $0.5 \mathrm{M})$ for spheroplast formation was determined by exposing organisms to lysozyme in the presence of different concentrations of proline (Fig. 2). The decline in the proportion of spheroplasts at proline concentrations below $0.5 \mathrm{M}$ was due to spheroplast lysis since the total count (cells + spheroplasts) followed a similar pattern (Fig. 2). The presence of $\mathrm{Ca}^{2+}$ or $\mathrm{Mg}^{2+}$ ions (10 mM) did not increase the stability of spheroplasts at low stabilizer concentrations. On the contrary, spheroplast yields were reduced in the presence of these ions (Fig. 2).

To be of use in a spheroplast fusion system, organisms must be capable of forming colonies in the presence of the stabilizer so that fused spheroplasts are able to grow once their cell wall has regenerated. To test the suitability of proline for colony formation and hence cell wall regeneration the ability of organisms to form colonies on proline-containing agar was determined. The presence of $0.5 \mathrm{M}$-proline in the agar completely inhibited colony formation. The highest concentration of proline that would permit colony growth was $35 \mathrm{~mm}$ and even then viability was erratic, varying from 2 to $79 \%$ in different experiments. In similar experiments with agar containing $0.5 \mathrm{M}$-glycerol the viability was $0.2 \%$.

These experiments showed that $0.5 \mathrm{M}$-proline is a suitable osmotic stabilizer for the formation of spheroplasts of Synechococcus without significant loss of viability in the short term. However, this stabilizer inhibited colony formation, indicating that spheroplast fusion is not yet a practical means of genetic analysis in Synechococcus PCC 6301. This is unfortunate since spheroplast fusion would have been suitable for large-scale genetic mapping and would have complemented transformation (Herdman, 1982) as a means of fine-structure analysis in this organism. Nonetheless, preparation of spheroplasts by the method described here would be of use in physiological studies, for example where viable spheroplasts are required (Pigott \& Carr, 1971; Peschek et al., 1982) or for the development of gentle lysis procedures for the recovery of intact cellular components.

This work was supported by the Australian Research Grants Scheme.

\section{REFERENCES}

GurR, E. (1965). In The Rational Use of Dyes in Biology and General Staining Methods, pp. 213-214. London: Leonard Hill.

Herdman, M. (1982). Evolution and genetic properties of cyanobacterial genomes. In The Biology of Cyanobacteria, 2nd edn, pp. 263-305. Edited by N. G. Carr \& B. A. Whitton. Oxford: Blackwell Scientific Publications.

HopwOOD, D. A. (1981). Genetic studies with bacterial protoplasts. Annual Review of Microbiology 35, 237272.

MARtin, H. H. (1963). Bacterial protoplasts-a review. Journal of Theoretical Biology 5, 1-34.

Peschex, G. A., Schoetterer, G. W W aestreiter, H. (1982). Oxidation of exogenous c-type cytochromes by intact spheroplasts of Anacystis nidulans. Archives of Microbiology 133, 222-224.

PigotT, G. H. \& CaRR, N. G. (1971). The assimilation of nucleic acid precursors by intact cells and protoplasts of the blue-green alga Anacystis nidulans. Archiv für Mikrobiologie 79, 1-6.

Rippka, R., Derublles, J., Waterbury, J. B., Herdman, M. \& Stanier, R. Y. (1979). Generic assignments, strain histories and properties of pure cultures of cyanobacteria. Journal of General Microbiology 111, 1-61. 